\title{
Influence of the Electrical Parameters on the Fabrication of Oxide Layers on the Surface of Al-1050 by a Plasma Electrolytic Process
}

\author{
Kyung-Su Nam, Jeong-Hwan Song*, and Dae-Young Lim*, \\ Department of Materials Engineering, Graduate School of PaiChai University, Daejeon 302-735, Korea \\ * Department of Information and Electronic Materials Engineering, PaiChai University, Daejeon 302-735, Korea \\ (Received February 28, 2012; Revised June 14, 2012; Accepted July 11, 2012)

\section{플라즈마 전해 산화법에 의한 Al-1050 표면상의 산화막 제조에 미치는 전기적 변수의 영향} \\ 남경수 · 송정환* · 임대영*† \\ 배재대학교 재료공학과 \\ *배재대학교 정보전자소재공학과 \\ (2012년 2월 28일 접수 ; 2012년 6월 14일 수정 ; 2012년 7월 11일 채택)
}

\begin{abstract}
Oxide layers were prepared by an environmentally friendly plasma electrolytic oxidation (PEO) process on an Al-1050 substrate. The electrolyte for PEO was an alkali-based solution with $\mathrm{Na}_{2} \mathrm{SiO}_{3}(8 \mathrm{~g} / \mathrm{L})$ and $\mathrm{NaOH}(3 \mathrm{~g} / \mathrm{L})$. The influence of the electrical parameters on the phase composition, microstructure and properties of the oxide layers formed by PEO were investigated by X-ray diffraction (XRD) and scanning electron microscopy (SEM). The voltage-time responses were recorded during various PEO processes. The oxides are composed of two layers and are mainly made of $\alpha$-alumina, $\gamma$-alumina and mullite phases. The proportion of each phase depends on various electrical parameters. It was found that the surface of the oxides produced at a higher current density and Ia/Ic ratio shows a more homogeneous morphology than those produced with the electrical parameters of a lower current density and lower $\mathrm{Ia} / \mathrm{Ic}$ ratio. Also, the oxide layers formed at a higher current density and higher Ia/Ic ratio show high micro-hardness levels.
\end{abstract}

Key words : PEO, $\alpha$-alumina, Al, Surface treatment, Electrical parameter

\section{1. 서 론}

고유가, 고효율의 사회로 접어들면서 기술적, 경제적인 모든 면에서 고려되고 있는 내구성이 좋고 경량이고 에 너지 효율이 우수한 재료를 사용하고자 하는 요구가 증 가하고 있다. 기존에 사용하던 철과 같은 금속을 가볍고 단단하며 부식저항성이 높은 재료로 대체하려고 노력하 고 있다. 대체 재료인 경금속들은 일반적으로 내식성, 내마 모성, 내산화성에 있어서 많은 문제점을 가지고 있다. ${ }^{1,2)}$ 이 런 문제들을 해결하고자 경금속에 대한 다양한 표면처리 를 통한 연구가 활발히 진행되고 있다.

대표적인 경금속의 표면처리 방법으로는 화학적 방법, 전기 화학적 방법 그리고 물리적인 방법으로 나눌 수 있 다. ${ }^{3)}$ 화학적 방법은 금속 표면에서 크로메이트 처리나 인

${ }^{\dagger}$ Corresponding author: Dae-Young Lim

E-mail : dylim@pcu.ac.kr

Tel : +82-42-520-5392 Fax : +82-42-520-5390
산염 처리와 같은 화학 반응을 통하여 내식성 있는 표면 피막을 형성하는 방법으로서 화성처리 (chemical conversion)가 있으며, 물리적 방법은 금속 표면에 도금을 하 는 방식으로 표면의 경도를 증진시키거나 내화학적 저항 성을 높인다. 전기 화학적인 방법으로는 양극산화기술 또 는 아노다이징이 있다. ${ }^{4)}$ 대규모 면적에서 비교적 적은 비 용으로 처리할 수 있는 장점 때문에 널리 사용되고 있지 만 인가전압이 $50 \mathrm{~V}$ 로 낮아 산화막층에 대해 요구되어지 는 물성에 도달하지 못하고 황산 등의 전처리가 필요하 기 때문에 친환경적이지 못하는 문제점들이 있다. ${ }^{5)}$

최근에는 양극산화기술과 비슷한 원리로 $\mathrm{Al}, \mathrm{Ti}, \mathrm{Mg}$ 와 같 은 부동태 금속 (passive metal)의 표면에 산화물 피막을 형 성시킬 수 있는 플라즈마 전해 산화법 (PEO (Plasma Electrolytic Oxidation) 또는 MAO (Micro Arc Oxidation)) 이라고 불리는 기술이 보고되고 있다. ${ }^{6-8)}$ 이 기술은 표면 의 강도를 강화시켜 줌으로써 외부 요인에 의한 긁힘, 부 식 등으로 인한 제품 손상을 막아 주고, 균일한 코팅 층 을 형성시킬 수 있다고 보고되고 있다. 그 밖에도 기존 
아노다이징 및 크롬 도금과 달리 규산염, 인산염, 알루민 산염 등과 같은 약한 알칼리 전해질에서 실행하기 때문 에 무연, 무취, 무독으로 공정 중 유독 물질을 발생시키 지 않아 자연 친화적이다. ${ }^{5,910)} \mathrm{PEO}$ 로 처리된 산화막층은 기계적, 전기적 및 열적 특성이 우수하고 인체에도 해가 없어 실생활에 쓰이는 휴대 전화, 노트북 컴퓨터, 자동차, 항공우주 부품, 엔지니어링 장비부품 및 생명의학 디바이 스 등 대부분의 기기 및 소재에 적용이 가능하다. ${ }^{1,2,11)}$

또한 기존의 아노다이징 처리에 비하여 훨씬 높은 전 압 $(350 \sim 600 \mathrm{~V})$ 에서 산화 피막이 형성되기 때문에 부 착성, 경도와 내화학적 저항성이 뛰어난 장점을 갖추고 있다고 많은 연구 보고가 되고 있다. ${ }^{3)}$ 하지만 $\mathrm{PEO}$ 처리 방법은 고전압을 인가하는데 있어서 전해액의 농도, 조성 등에 따라서 조절이 쉽지 않은 단점이 있고 표면 처리를 위한 금속 모재 합금 성분의 조성 변화에 따라서 많은 변 수가 있다. PEO 처리를 하는 경우에 인가 전압의 크기, 전류량에 따른 변화, 펄스 폭, 바이폴라 전압의 유무와 상 대적 크기, 지속시간, 전원 공급 장치의 직류 (DC) 혹은 불균형 교류 (AC) 등 전기적 부분에서의 공정 변수도 대 단히 많다. ${ }^{3,8,12)}$ 특히 이런 전기적 변수뿐만 아니라 PEO 공정상의 변수에 있어서 많은 부분들이 아직 명확히 밝 혀지지 못한 상태이다.

따라서, 본 연구에서는 $\mathrm{Al}-1050$ 에 대한 PEO 처리에 있 어서 전해질의 농도와 조성을 고정시키고 주파수, 전류밀 도, 전류 비와 같은 $\mathrm{PEO}$ 공정의 전기적 변수들이 형성된 산화 피막의 결정구조, 단면 및 표면구조, 표면조도, 경도, 피막두께 등에 미치는 영향을 연구하고자 하였다.

\section{2. 실험방법}

본 연구에 사용된 $\mathrm{Al}$ 은 실험 중에 일어날 수 있는 변 수들을 최대한 줄이기 위하여 일반적으로 $\mathrm{Al}$ 합금을 제 조할 때 첨가되는 $\mathrm{Si}, \mathrm{Cu}, \mathrm{Mn}, \mathrm{Mg}, \mathrm{Fe}, \mathrm{Cr}, \mathrm{Ti}$ 등이 거 의 포함되어 있지 않은 $\mathrm{Al}-1050$ 을 사용하였다. $\mathrm{Al}$ 이 $99 \%$ 이상으로 거의 순수한 알루미늄만으로 구성되어 있는 Al1050 합금(주) 대한알루미늄)의 조성 원소는 Table 1과 같 다. $\mathrm{Al}$ 판재는 $50 \times 50 \times 1 \mathrm{~mm}^{3}$ 로 가공하여 사용하였다.

본 연구에 사용된 장비는 러시아에서 자체 개발한 $\mathrm{PEO}$ 장치로서 교류 작동전압 $\sim 650 \mathrm{~V}$, 작동전류 $20 \mathrm{~A}$ 의 장치 로서 바이폴라가 가능할 수 있게 되어 있다. 전해조의 용 량은 $50 \mathrm{~L}$ 이며 양쪽 면에 스테인레스 스틸의 전극판으로 구성되어 있고, 전해액의 균일한 분포를 위하여 전해조 내부에 stirrer 또는 공기버블의 장치가 설치되어 실험 동

Table 1. Chemical Composition of Al-1050 Substrate （wt\%)

\begin{tabular}{ccccccccc}
\hline $\mathrm{Si}$ & $\mathrm{Fe}$ & $\mathrm{Cu}$ & $\mathrm{Mn}$ & $\mathrm{Mg}$ & $\mathrm{Zn}$ & $\mathrm{Ti}$ & $\mathrm{Cu}+\mathrm{Si}$ & $\mathrm{Al}$ \\
\hline 0.25 & 0.4 & 0.05 & 0.05 & 0.05 & 0.05 & 0.03 & 0.08 & more than 99.04 \\
\hline
\end{tabular}

안에 전해액이 충분히 교반될 수 있도록 하였다. Fig. 1 은 $\mathrm{PEO}$ 장치의 구성을 모식도로 나타낸 것이다.

본 실험의 PEO 처리공정은 Fig. 2에 나타낸 순서대로 먼저 $\mathrm{Al}$ 판재 표면에 부착되어 있는 불순물 등을 제거하 기 위하여 증류수와 에탄올을 사용하였다. 전해액은 증류 수에 주로 $\mathrm{Na}_{2} \mathrm{SiO}_{3}$ 물유리를 $8 \mathrm{~g} / \mathrm{L}$ 의 농도로 하고 $\mathrm{NaOH}$ $3 \mathrm{~g} / \mathrm{L}$ 를 첨가한 것을 사용하였다. $\mathrm{PEO}$ 처리를 위한 전기 적인 변수로, Duty cycle은 $40 \%$, Anodic 전류밀도는 14 와 $16 \mathrm{~A} / \mathrm{dm}^{2}$ 로, 주파수는 100 와 $200 \mathrm{~Hz}$, 음극과 양극의 전류 비인 $\mathrm{Ia} / \mathrm{Ic}$ 를 $1.0 \sim 1.5$ 로 변화시켜 산화 피막을 형성하였다 (Table 2). 처리시간은 30 분으로 고정시키고 전해조의 온 도는 냉각시스템을 이용하여 약 $30^{\circ} \mathrm{C}$ 를 유지시켰다. $\mathrm{PEO}$ 처리공정이 끝난 후에 생성된 산화막은 증류수를 이용하 여 세척하고 건조하였다.

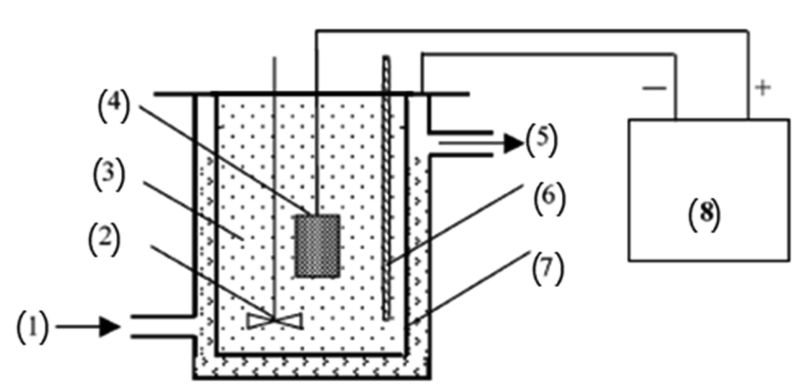

Fig. 1. Schematic diagram of the equipment system used for PEO treatment: (1) cooling water inlet, (2) mixer, (3) electrolyte, (4) sample (anode), (5) cooling water outlet, (6) thermocouple, (7) stainless steel (cathode), and (8) power supply unit.

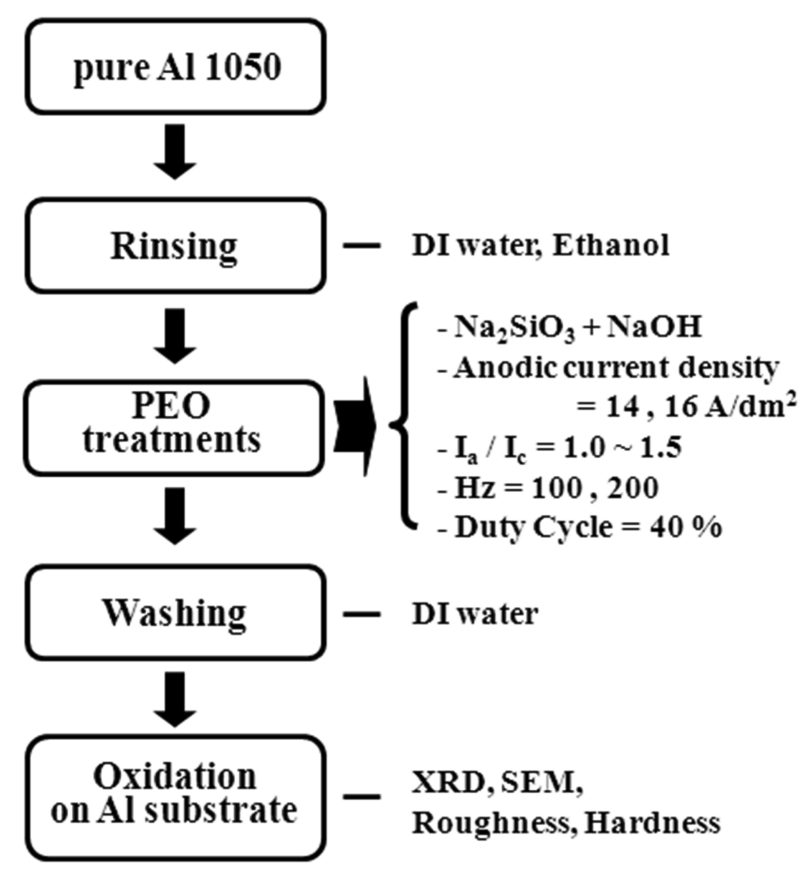

Fig. 2. Experimental procedure of PEO process. 
Table 2. Electric Parameter for PEO Treatment

\begin{tabular}{|c|c|c|c|}
\hline $\mathrm{A} / \mathrm{dm}^{2}$ & $\mathrm{Ia} / \mathrm{Ic}$ & $100 \mathrm{~Hz}$ & $200 \mathrm{~Hz}$ \\
\hline 14 & 1.2 & Process A & Process $\mathrm{F}$ \\
\hline 14 & 1.5 & Process B & Process $G$ \\
\hline 16 & 1.0 & Process C & Process H \\
\hline 16 & 1.2 & Process D & Process I \\
\hline 16 & 1.5 & Process E & Process $\mathrm{J}$ \\
\hline
\end{tabular}

Al-1050 위에 형성된 산화막층에 대한 결정상은 X-ray Diffractometer (Shimazu, D1w, Japan)으로 분석하였다 $\left(\mathrm{CuK \alpha} \alpha_{1}, 2 \% \mathrm{~min}, 2 \theta=10-80^{\circ}\right)$. 산화막층의 표면 및 단면 형상은 SEM (HITACHI, S-4800, Japan)을 사용하여 관찰 하였다. 두께 측정에는 Positector (Delfelsko, Positector $6000, \mathrm{USA}$ )를 사용하여 전체 시편의 각 부분에 대해 5회 행하여 평균값을 나타내었고 표면조도는 Perthometer (Mahr, PGK 120, Germany)를 사용하였다. 표면경도는 Micro Vickers Hardness Tester (MATSUZAWA, MMT-7, Japan)을 사용하여 $50 \mathrm{~g}$ 의 하중을 주어 측정하였다.

\section{3. 결과 및 고찰}

Fig. 3은 전류밀도 14 와 $16 \mathrm{~A} / \mathrm{dm}^{2}$ 의 조건에서 정전류 방 식으로 $\mathrm{AC}-\mathrm{PEO}$ 공정을 행하였을 때, 처리시간에 따른 전 압의 변화를 나타낸 것이다. 이때, 주파수는 $100 \mathrm{~Hz}$ 이고 $\mathrm{Ia} / \mathrm{Ic}$ 의 전류비는 1.5 였다. $\mathrm{PEO}$ 과정은 전압의 증가에 따 라 크게 두 가지 단계로 나누어 설명할 수 있다. 초기에 서 60초 사이의 짧은 시간에 500 530 V까지 전압이 비교 적 직선적으로 급격히 증가함을 볼 수 있다. 양 전극의 샘플과 전해질에서, 수소 또는 산소의 분리와 양극 전압 의 급격한 증가로 항복 값에 도달하게 되면 강한 전류장 에 의해 $\mathrm{Al}$ 의 표면 위에 다수의 작은 플라즈마가 균일하 게 분포되어 발생하게 된다. $\mathrm{PEO}$ 과정의 초기 단계로 $\mathrm{Al}-$

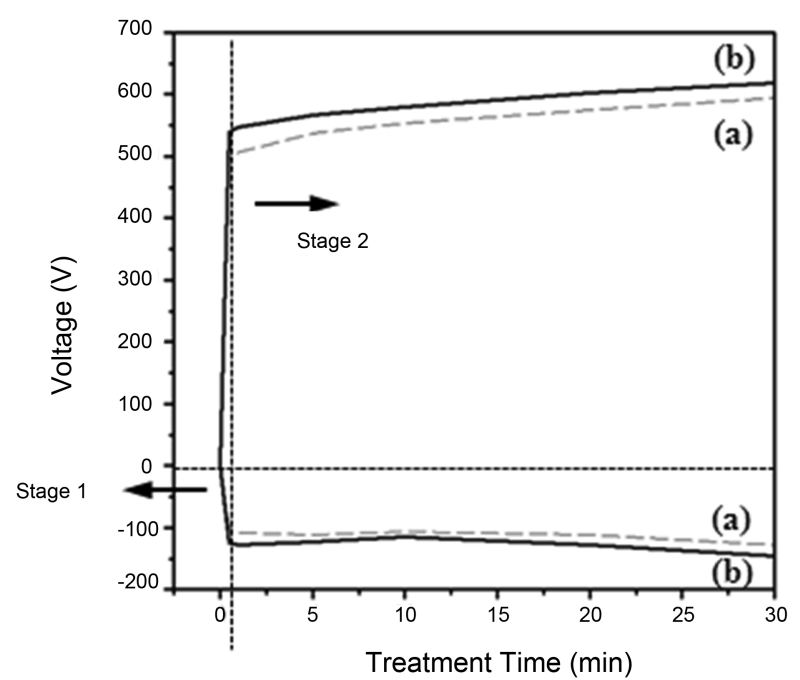

Fig. 3. Voltage vs. time in treatment of PEO on Al-1050 at the condition of (a) Process B $\left(14 \mathrm{~A} / \mathrm{dm}^{2}\right)$ and (b) Process $\mathrm{E}\left(16 \mathrm{~A} / \mathrm{dm}^{2}\right)$ at $100 \mathrm{~Hz}, \mathrm{Ia} / \mathrm{Ic}=1.5$.

1050 금속 표면을 용해시켜 높은 전기 저항을 가지는 얇 은 장벽층이 형성된다. ${ }^{13)}$ 두 번째 단계에서의 전압은 보 다 완만하게 증가하였고 그 이후 안정하게 되었다. 산화 막의 두께가 증가함에 따라 시편은 절연성을 띄게 되어 플라즈마 스파크의 밀도는 감소하지만 처리시간이 증가 함에 따라 스파크들의 크기는 점차적으로 증가하였다. 이 는 생성된 산화막의 약한 부분에서 절연파괴가 일어나며 지속적으로 매우 치밀하고 단단한 산화막을 형성하게 된 다. Fig. 3에 나타낸 것과 같이 PEO 처리에 이용된 다른 전기적 조건에서의 전압-시간 곡선은 비슷한 경향을 나타 내지만 전류밀도가 클수록 도달하는 최대 전압이 증가하 는 것을 알 수 있었다.

Fig. 4은 PEO 처리를 한 각 샘플들에 대한 X-선 회절 패턴을 나타낸 것이다. $\mathrm{Al}$ 의 표면에 형성된 산화막층의 결정상은 모든 샘플에서 비슷한 XRD 피크를 나타내며
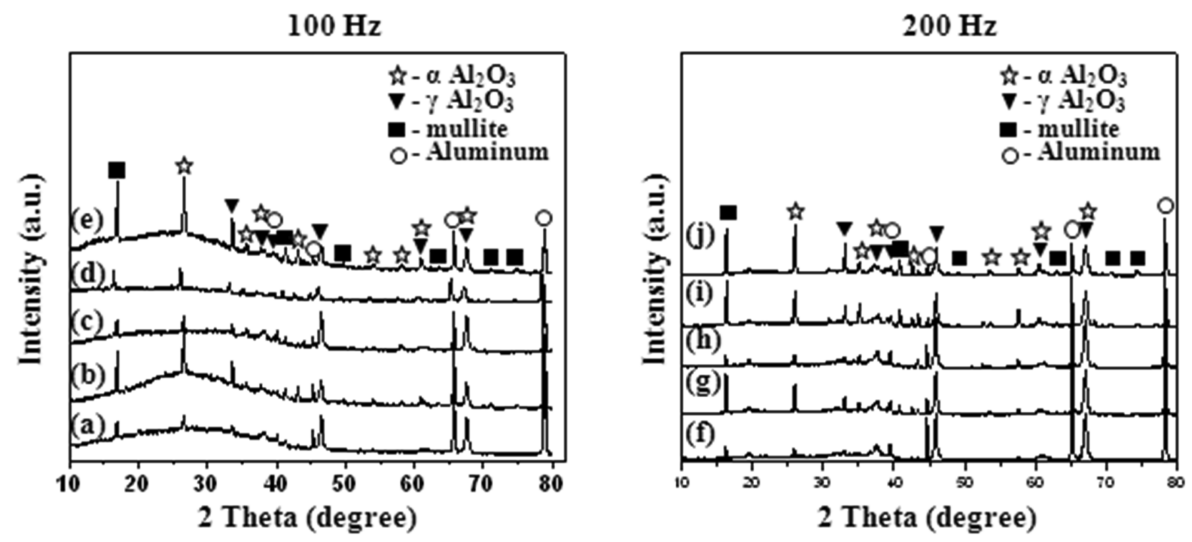

Fig. 4. XRD patterns of oxide layers obtained by PEO at the conditions of (a) Process A, (b) Process B, (c) Process C, (d) Process D, (e) Process E for 100 Hz, 30 min and (f) Process F, (g) Process G, (h) Process H, (i) Process I, and (j) Process J for 200 Hz, 30 min. 
$\alpha$-alumina와 $\gamma$-alumina가 주된 상이며, 일부 비정질상의 존 재도 나타나고 있다. 알루미나는 금속표면과 전해액 사이 에서 방전 채널을 통한 플라즈마 열화학 반응에 의해 형 성된다. 일반적으로 $\alpha$-alumina는 모든 온도영역에서 열역 학적으로 안정한 상이고 $\gamma$-alumina는 불안정한 상으로 알 려져 있다. 또한 불안정한 상인 $\gamma$-alumina은 쉽게 형성이 되고 $1273 \mathrm{~K}$ 이상의 높은 온도에서 $\alpha$-alumina로 상전이가 일어난다. ${ }^{14)}$ 따라서 인가된 전압이 크고 전류의 양이 많 다면 표면에서 발생된 플라즈마의 양이 많아지고 이에 따 라 산화 피막에 많은 양의 열이 전달되기 때문에 고온의 영역에서 안정한 $\alpha$-alumina상이 많이 생성되어지는 것으 로 사료된다. 또한 이런 결정상뿐만 아니라 열적, 화학적 으로 안정성을 가지는 mullite $\left(3 \mathrm{Al}_{2} \mathrm{O}_{3} \cdot 2 \mathrm{SiO}_{2}\right)$ 로 대표되는 $\mathrm{Al}-\mathrm{Si}-\mathrm{O}$ 계의 결정상도 나타나는 것을 알 수 있었다. 이것 은 $\mathrm{PEO}$ 처리하는 동안 전해액으로 사용된 $\mathrm{Na}_{2} \mathrm{SiO}_{3}$ 가 $\mathrm{Al}$ 과 반응하여 형성되는 것으로 사료된다.

Table 3에 나타낸 것과 같이 각각의 전기적 변수에 의 해 $\mathrm{PEO}$ 처리하여 형성된 산화막층의 $\mathrm{XRD}$ 패턴의 피크 강도를 가지고 계산하여 각각의 결정상에 대한 함량을 얻 을 수 있었다. ${ }^{6)} \alpha$-alumina상의 함량 $(P \alpha)$ 은

$$
P \alpha=\frac{\alpha}{(\alpha+\gamma+M)} \times 100
$$

의 식으로 얻었다. 여기서 $\alpha$ 는 $\alpha$-alumina의 (012) 피크강 도, $\gamma$ 는 $\gamma$-alumina의 (400) 피크강도, 그리고 $\mathrm{M}$ 은 mullite의 (110) 피크강도를 나타낸다. 전류밀도와 전류비가 증가할수 록 $\gamma$-alumina상은 감소하는 반면에 $\alpha$-alumina상과 mullite
상은 증가하는 것을 알 수 있었다.

Fig. 5는 Al-1050에 각각의 조건에 따라 PEO 처리한 후 형성된 산화 피막의 표면구조를 $\mathrm{SEM}$ 으로 관찰한 것이다. 모든 샘플에 있어서 산화 피막의 표면에 분화구 흔적과 분화구에서 분출되어 형성된 많은 플라즈마 방전 생성물 을 포함하고 있는 것을 볼 수 있었다. 플라즈마 방전이 발생할 때, 표면에서 미세하게 폭발하는 고온의 플라즈마 에 의해 $\mathrm{Al}$ 기판이 용융되고 분출된 $\mathrm{Al}$ 이 전해질의 다른 이온과 산소와 열화학 및 전기화학 반응을 하고 급속히 냉각되면서 굳어지게 된다. 처리시간이 길어질수록 더 높 은 전압을 가해지게 되면 절연파괴가 일어나고 이런 방 전 채널을 통해 지속적으로 높은 융점을 가지는 산화 피 막이 기판 위에 골고루 형성된다. 방전 채널에서 산화막 의 축적은 채널 크기의 감소를 초래하고 플라즈마 방전 이 더 이상 일어나지 않으면 코팅 표면에 분화구와 같은 모양이 점차 사라지게 된다.

Fig. 5(a)와 (d)와 같이 전류밀도가 작을수록 절연파괴가 일어나기 어렵기 때문에 방전 채널을 통해 분출되어 나 오는 산화물들의 크기가 작고 이런 방전 채널이 채워지 지 못하고 다수의 작은 기공으로서 존재하는 것을 볼 수 있었다. 반면에 Fig. 5(c)와 (f)와 같이 높은 전류밀도에서 $\mathrm{PEO}$ 처리한 산화막 표면에서는 방전 채널을 통해 분출 되어 나오는 산화물들의 크기가 크며 치밀화되고 이런 생 성물들이 기공을 채우게 되어 기공이 사라지는 것을 볼 수 있었다.

또한 Fig. 5(a)에서 나타낸 것처럼 플라즈마에 의한 분 출에 의해 생성된 기공의 주변에 균열이 발생하는 것을
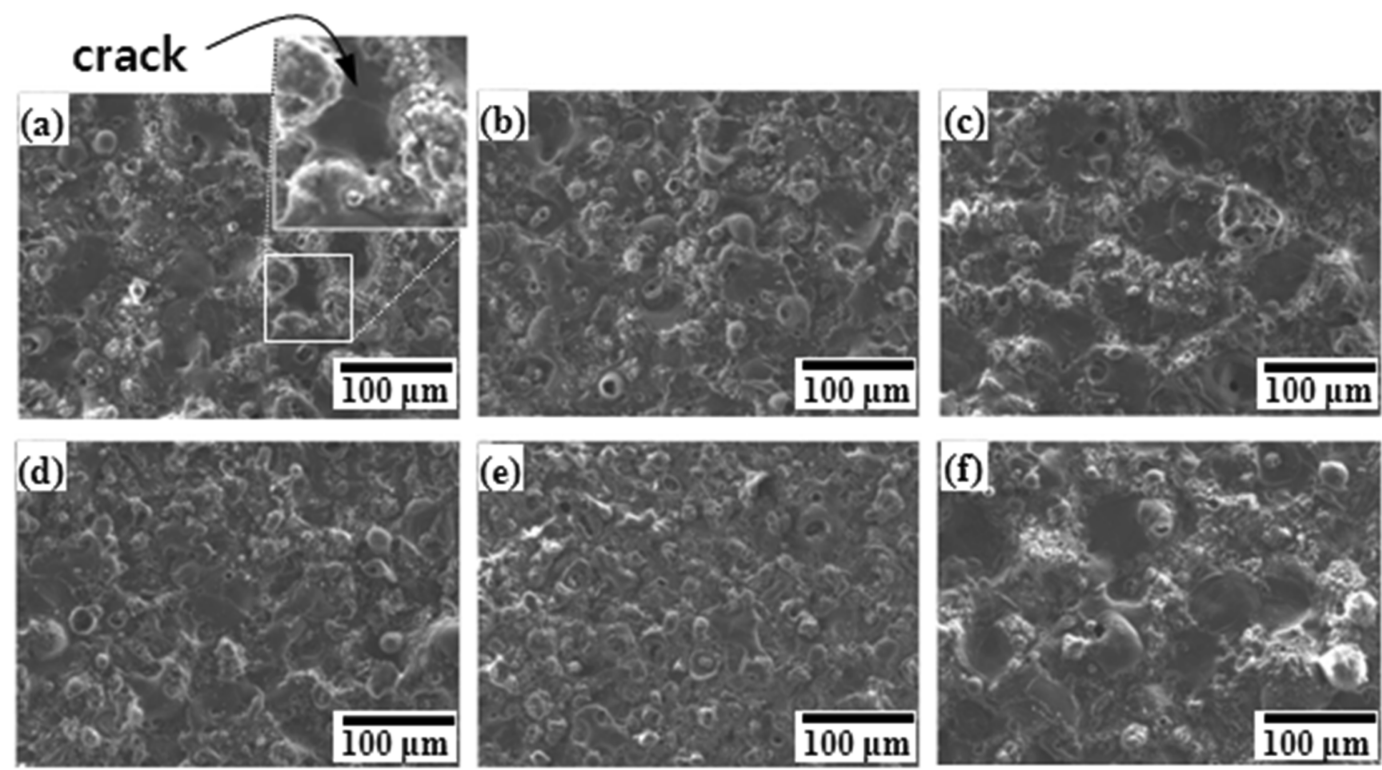

Fig. 5. SEM surface images of oxide layers obtained by PEO at the conditions of (a) $14 \mathrm{~A} / \mathrm{dm}^{2}, 1.5 \mathrm{Ia} / \mathrm{Ic}$, (b) $16 \mathrm{~A} / \mathrm{dm}^{2}, 1.2 \mathrm{Ia} / \mathrm{Ic}$, (c) $16 \mathrm{~A} / \mathrm{dm}^{2}, 1.5 \mathrm{Ia} / \mathrm{Ic}$ for $100 \mathrm{~Hz}, 30 \mathrm{~min}$ and (d) $14 \mathrm{~A} / \mathrm{dm}^{2}, 1.2 \mathrm{Ia} / \mathrm{Ic}$, (e) $16 \mathrm{~A} / \mathrm{dm}^{2}, 1.0 \mathrm{Ia} / \mathrm{Ic}$, (f) $16 \mathrm{~A} / \mathrm{dm}^{2}, 1.5 \mathrm{Ia} / \mathrm{Ic} \mathrm{for} 200 \mathrm{~Hz}$, 30 min. Insert shows SEM image for crack part on the surface in Fig. 5(a). 

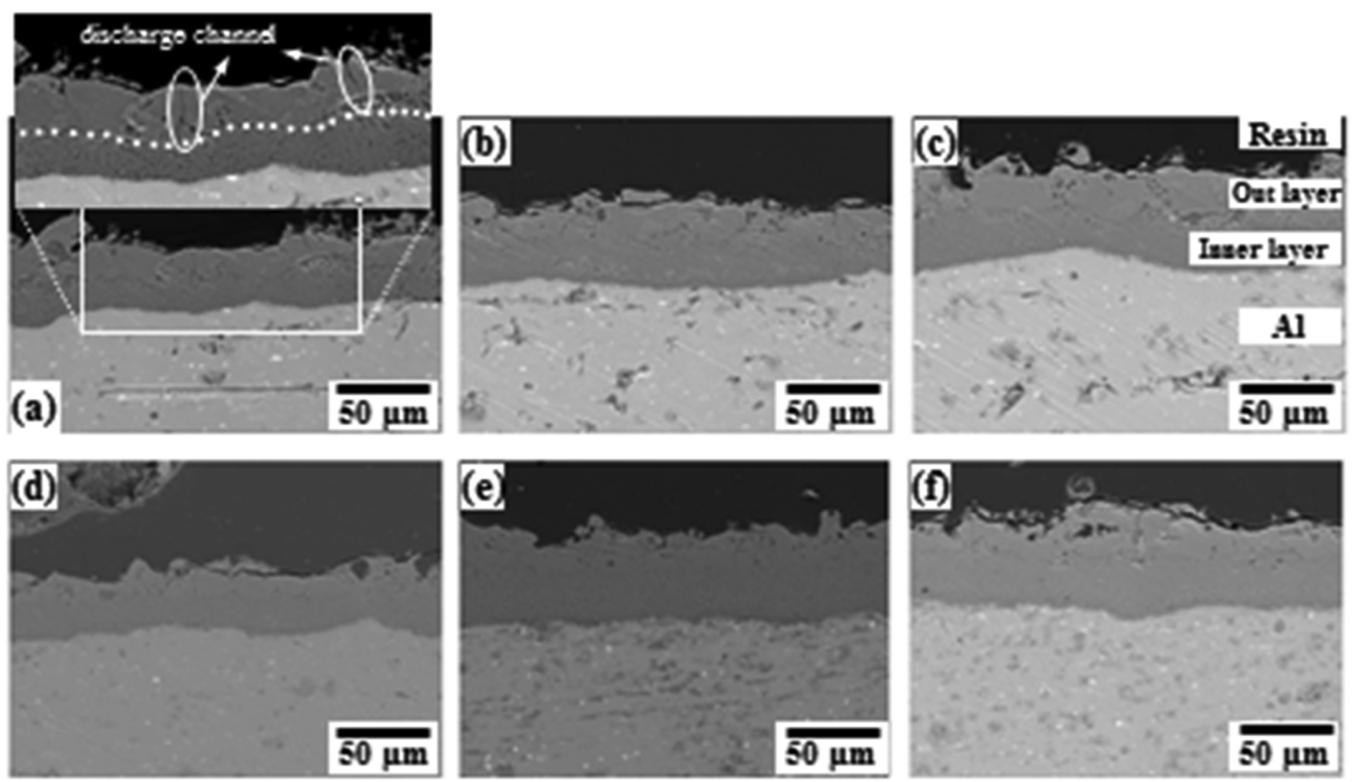

Fig. 6. SEM cross section images of oxide layers obtained by PEO at the conditions of (a) $14 \mathrm{~A} / \mathrm{dm}^{2}, 1.5 \mathrm{Ia} / \mathrm{Ic}$, (b) $16 \mathrm{~A} / \mathrm{dm}^{2}, 1.2 \mathrm{Ia} /$ Ic, (c) $16 \mathrm{~A} / \mathrm{dm}^{2}, 1.5 \mathrm{Ia} / \mathrm{Ic}$ for $100 \mathrm{~Hz}, 30 \mathrm{~min}$ and (d) $14 \mathrm{~A} / \mathrm{dm}^{2}, 1.2 \mathrm{Ia} / \mathrm{Ic}$, (e) $16 \mathrm{~A} / \mathrm{dm}^{2}, 1.0 \mathrm{Ia} / \mathrm{Ic}$, (f) $16 \mathrm{~A} / \mathrm{dm}^{2}, 1.5 \mathrm{Ia} / \mathrm{Ic}$ for $200 \mathrm{~Hz}, 30 \mathrm{~min}$. Insert shows SEM image for double layer and discharge channel on cross section oxides in Fig. 6(a).

볼 수 있는데, 이는 $\mathrm{Al}$ 모재와 산화 피막간의 열팽창계수 의 차이 또는 고온에서 형성되는 산화 피막이 상온의 전 해질과 접촉에 의해 급랭되면서 발생되는 열 충격에 의 한 균열이라 사료된다.

각각의 조건에 따라 $\mathrm{Al}-1050$ 을 30 분 동안 $\mathrm{PEO}$ 처리하 여 형성된 산화 피막에 대해 단면 $\mathrm{SEM}$ 으로 관찰한 것을 Fig. 6에 나타내었다. 기존 연구에서는 $\mathrm{PEO}$ 로 형성된 산 화피막의 바깥 부분은 기공이 많은 다공층으로 이루어져 있다고 보고되고 있다. ${ }^{1,8)}$ 본 연구 결과에서는 $\mathrm{PEO}$ 처리 된 모든 산화 피막층들은 비교적 치밀한 구조로 이루어 져 있는 것이 관찰되었다. 그러나 자세히 들여다 보면 형 성된 산화 피막은 두 개의 층으로 나누어져 있는 것을 볼 수 있었다. $\mathrm{Al}$ 모재 위에 형성된 내부층은 치밀하게 이루 어져 있고 표면과 가까운 피막 바깥층은 커다란 주상구 조로 치밀하게 구성되어 있지만 방전 채널이 관찰되는 것 을 볼 수 있었다. 이러한 방전 채널은 산화 피막 특성을 저하시키는 역할로 작용할 것으로 사료된다.

$\mathrm{Al}$ 모재와 그 위에 형성된 산화 피막층과의 계면에서 는 어떠한 결함도 보이질 않고 치밀하게 부착되어 있는 것을 볼 수 있었다. 또한 산화 피막의 두께도 전체 영역에 걸쳐서 균일하게 Fig. 6(a)와 (d)는 약 $40 \mu \mathrm{m}$, Fig. 6(c)와 (f) 는 약 $60 \mu \mathrm{m}$ 의 두께로 이루어져 있음을 알 수 있었다. 주 파수와는 관계없이 전류밀도가 커질수록 두께가 증가하 는 것을 알 수 있었다.

일반적으로 기존의 $\mathrm{PEO}$ 방법은 산화 피막의 두께가 두 꺼워질수록 전기저항이 커져 발생되는 플라즈마가 줄어 들고 불규칙하게 되면서 표면에 많은 기공이 형성되어 거

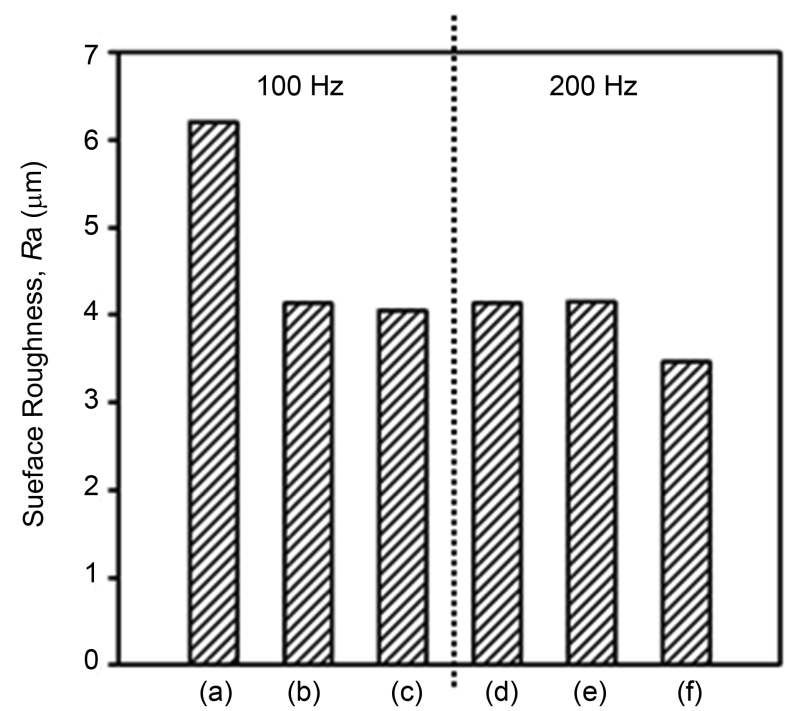

Fig. 7. Roughness of oxides obtained by $\mathrm{PEO}$ at the conditions of (a) $14 \mathrm{~A} / \mathrm{dm}^{2}, 1.5 \mathrm{Ia} / \mathrm{Ic}$, (b) $16 \mathrm{~A} / \mathrm{dm}^{2}, 1.2 \mathrm{Ia} / \mathrm{Ic}$, (c) $16 \mathrm{~A} / \mathrm{dm}^{2}, 1.5 \mathrm{Ia} / \mathrm{Ic}$ for $30 \mathrm{~min}$ and (d) $14 \mathrm{~A} / \mathrm{dm}^{2}, 1.2$ $\mathrm{Ia} / \mathrm{Ic}$, (e) $16 \mathrm{~A} / \mathrm{dm}^{2}, 1.0 \mathrm{Ia} / \mathrm{Ic}$, (f) $16 \mathrm{~A} / \mathrm{dm}^{2}, 1.5 \mathrm{Ia} / \mathrm{Ic}$ for $30 \mathrm{~min}$.

품형태의 표면구조를 가지므로 표면 조도가 나빠진다고 보고되고 있다. ${ }^{8}$ Fig. 7은 각 샘플들에 대한 평균 표면 조 도 $(\mathrm{Ra})$ 값을 나타낸 것이다. 기존 보고와 달리, Fig. 6(c) 와 (f)에서의 단면 SEM 결과와 비교하여 보면 두꺼운 산 화 피막층을 가지는 샘플에서도 표면 조도가 작아지는 것 을 알 수 있었다. Fig. 5의 표면 구조 사진에서처럼 충분 한 전압을 갖지 못하는 약한 플라즈마 $\mathrm{PEO}$ 처리 시 시 


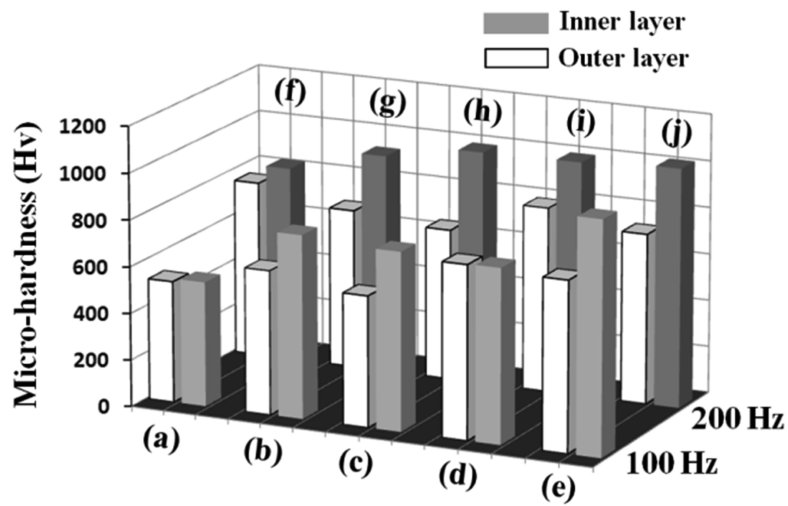

Fig. 8. Micro-hardness of oxide layers coated by PEO at the conditions of (a) Process A, (b) Process B, (c) Process C, (d) Process D, (e) Process E for $100 \mathrm{~Hz}, 30 \mathrm{~min}$ and (f) Process F, (g) Process G, (h) Process H, (i) Process I, and (j) Process J for $200 \mathrm{~Hz}, 30 \mathrm{~min}$.

편의 전체적으로 다수의 작은 산화 피막들이 무수히 생 성되어 표면 조도가 나빠지게 된다. 반면에 전류밀도가 높아지면 용융되어 분출되는 입자들의 크기가 커지고 전 체적으로 좀 더 매끈한 형상을 나타내어 표면 조도가 좋 아진다고 사료된다.

Fig. 8은 각 산화 피막들에 대한 마이크로 비커스 경도 를 나타낸 것이다. $\mathrm{Al}$ 합금 (Al $99 \%$ 이상) 중 모재로 이 용한 1000 계열의 $\mathrm{Al}-1050$ 은 약 $50 \mathrm{Hv}$ 의 가장 낮은 경도 값을 가진다. 경도 측정은 샘플의 단면을 산화 피막 바깥 층에서부터 $\mathrm{Al}$ 모재쪽 방향으로 측정한 결과이다. 모든 샘플에 있어서 바깥층의 경도보다 내부층에서 높은 경도 값이 얻어졌다. 낮은 주파수 $100 \mathrm{~Hz}$ 이고 상대적으로 작은 전류 비와 전류밀도에서 얻어진 산화피막은 약 $520 \mathrm{Hv}$ 의 낮은 경도를 나타내었지만 전류 비와 전류밀도가 증가함 에 따라 바깥층의 경도는 $750 \mathrm{Hv}$ 로 약간 증가하는 반면 에 내부층은 $1000 \mathrm{Hv}$ 의 보다 큰 경도 값을 얻을 수 있었 다. 또한 높은 주파수인 $200 \mathrm{~Hz}$ 에서 PEO 처리하여 얻어 진 산화피막의 경도를 보면, 바깥층의 피막은 비슷한 $650 \sim 750 \mathrm{Hv}$ 의 경도 값을 가지는 반면에 $\mathrm{Al}$ 모재 위에 형성된 치밀한 산화피막의 내부층은 전류밀도와 전류 비 가 커질수록 경도 값이 $850 \sim 1050 \mathrm{Hv}$ 로 점진적으로 증가 하는 알 수 있었다. 따라서 Table 3에서 얻어진 결과처럼
내부층에서부터 $\gamma$-alumina의 함량보다 $\alpha$-alumina의 함량 이 많아지면서 경도가 증가하게 되어 기계적 특성이 우수 한 산화물층이 형성되는 것으로 사료된다. 이런 $\alpha$-alumina 상의 생성을 위해서는 충분한 전류밀도, 전류 비에 의한 고 온의 플라즈마가 필요하다는 것을 알 수 있었다.

\section{4. 결 론}

증류수에 주로 $\mathrm{Na}_{2} \mathrm{SiO}_{3}$ 물유리를 $8 \mathrm{~g} / \mathrm{L}$ 의 농도로 하고 $\mathrm{NaOH} 3 \mathrm{~g} / \mathrm{L}$ 를 첨가한 것을 전해액으로 사용하였고, 플라 즈마 전해 산화법 (PEO) 처리를 위한 전기적인 변수로, Duty cycle은 $40 \%$, 양극 전류밀도는 14 와 $16 \mathrm{~A} / \mathrm{dm}^{2}$ 로, 주 파수는 100 와 $200 \mathrm{~Hz}$, 양극과 음극의 전류비인 $\mathrm{Ia} / \mathrm{Ic}$ 를 $1.0 \sim 1.5$ 로 변화시켜 $\mathrm{Al}-1050$ 에 대하여 산화 피막을 형성 시킨 후 물성을 분석하였다.

각 샘플들에 대한 PEO 처리시간은 30 분으로 약 $40 \sim 60 \mu \mathrm{m}$ 의 산화 피막을 얻을 수 있었다. 형성된 산화 피막의 결정 상은 $\alpha$-alumina, $\gamma$-alumina 그리고 mullite의 세 개의 상이 존재하는 것을 알 수 있었다. 전류밀도 및 전류비가 클수 록 도달하는 최대 전압의 증가로 인하여 플라즈마의 양 이 많아지고 이에 따라 산화 피막에 많은 양의 열이 전 달되기 때문에 불안정상인 $\gamma$-alumina상 보다는 모든 온도 영역에서 안정한 $\alpha$-alumina상이 많이 생성되는 것을 알 수 있었다. 또한 이 조건에서 형성된 산화 피막의 표면은 보다 매끄럽고 경도 특성에 좋은 영향을 미치는 것을 알 수 있었다. 따라서 PEO 처리시 우수한 물리적, 기계적 물 성을 갖는 산화 피막을 형성하기 위해서는 충분한 전류 밀도와 전류 비에 따른 높은 전압이 필요하다는 것을 알 수 있었다.

\section{Acknowledgment}

본 논문은 2011년도 정부(교육과학기술부)의 재원으로 한국연구재단의 일반연구자 지원사업 지역대학우수과학 자 (No.2011-0011304)의 연구수행으로 인한 결과물임을 밝히며, 이에 감사 드립니다.

\section{REFERENCES}

Table 3. Variation of $P$ of Oxide Layer Obtained by PEO Treatment with Different Electric Parameter

\begin{tabular}{|c|c|c|c|c|c|c|}
\hline \multirow{2}{*}{$\mathrm{A} / \mathrm{dm}^{2}, \mathrm{Ia} / \mathrm{Ic}$} & \multicolumn{3}{|c|}{$100 \mathrm{~Hz}$} & \multicolumn{3}{|c|}{$200 \mathrm{~Hz}$} \\
\hline & $\alpha-\mathrm{Al}_{2} \mathrm{O}_{3}$ & $\gamma-\mathrm{Al}_{2} \mathrm{O}_{3}$ & Mullite & $\alpha-\mathrm{Al}_{2} \mathrm{O}_{3}$ & $\gamma-\mathrm{Al}_{2} \mathrm{O}_{3}$ & Mullite \\
\hline $14 / 1.2$ & 11 & 75 & 14 & 12 & 70 & 18 \\
\hline $14 / 1.5$ & 43 & 20 & 37 & 24 & 38 & 38 \\
\hline $16 / 1.0$ & 20 & 52 & 28 & 14 & 70 & 16 \\
\hline $16 / 1.2$ & 40 & 23 & 37 & 33 & 32 & 35 \\
\hline $16 / 1.5$ & 44 & 14 & 42 & 40 & 24 & 36 \\
\hline
\end{tabular}

(\%) 
1. W. B. Xue, Ch.wang, Y. L. Li, Z. h.W. Deng, R.Y. Chen, and T. H. Zhang, "Effect of Microarc Discharge Surface Treatment on the Tensile Properties of $\mathrm{Al}-\mathrm{Cu}-\mathrm{Mg}$ alloy," Mater. Lett., 56 737-43 (2002).

2. S. V. Gnedenkov, O. A. Khrisanfova, A. G. Zavidnaya, S. L. Sinbrukhov, A. N. Kovryanov, T. M. Scorobogatova, and P. S. Gordienko, "Production of Hard and Heat-resistant Coatings on Aluminum using a Plasma Micro-discharge," Surf. Coat. Technol., 123 24-8 (2000).

3. B. Y. Kim, D. Y. Lee, Y. N. Kim, M. S. Jeon, W. S. You, and K. Y. Kim, "Analysis of Oxide Coatings Formed on A11050 Alloy by Plasma Electrolytic Oxidation(in Korean)," J. Kor. Ceram. Soc., 46 [3] 295-300 (2009).

4. G. K.Won and T. K.Choi, Anode Oxidation Technology (in Korean); Vol. 2, pp. 3-16, DonghHwaTechnology Publishing Co, Gyeonggi-do, 2008.

5. F. Mécuson, T. Czerwiec, T. Belmonte, L. Dujardin, A. Viola, and G. Henrion, "Diagnostics of an Electrolytic Microarc Process for Aluminum Alloy Oxidation," Surf. Coat. Technol., 200 804-8 (2005).

6. W. Xue, Z. Deng, and Y. Lai, R. Chen, "Analysis of Phase Distribution for Ceramic Coatings Formed by Microarc Oxidation on Aluminum Alloy," J. Am. Ceram. Soc., 81 [5] 1365-68 (1998).

7. A. L. Yerokhin, L. O. Snizhko, N. L. Gurevina, A. Leyland, A. Plikington, and A. Matthews, "Discharge Characterization in Plasma Electrolytic Oxidation of Aluminum," $J$.
Phys., D. Appl. Phys., 36 2110-20 (2003).

8. A. L. Yerokhin, X. Nie, A. Leyland, A. Matthews, and S. J. Dowey, "Plasma Electrolysis for Surface Engineering," Surf. Coat. Technol., 122 73-93 (1999).

9. R. C. Barik, J. A. Wharton, R. J. K. Wood, K. R. Stokes, and R. L. Jones, "Corrosion, Erosion and Erosion-corrosion Performance of Plasma Electrolytic Oxidation (PEO) Deposited $\mathrm{Al}_{2} \mathrm{O}_{3}$ Coatings," Surf. Coat. Technol., 199 158-67 (2005).

10. G. Lv, W. Gu, H. Chen, W. Feng, M. L. Khosa, L. Li, E. Niu, G. Zhang, and S.-Z. Yang, "Characteristic of Ceramic Coatings on Aluminum by Plasma Electrolytic Oxidation in Silicate and Phosphate," Appl. Surf. Sci., 253 2947-52 (2006).

11. J. Tian, Lou, Sh. K. Qi, and X. J. Sun, "Structure and Antiwear Behavior of Micro-arc Oxidized Coatings on Aluminum Alloy," Surf. Coat. Technol., 154 1-7 (2002).

12. B. H. Long, H. H. Wu, B.Y. Long, J. B. Wang, N. D. Wang, X. Y. Lü, Z. S. Jin, and Y. Z. Bai, "Characteristics of Electric Parameters in Aluminum Alloy MAO Coating Process," $J$. Phys. D: Appl. Phys., 38 3491-96 (2005).

13. S. Xin, L. Song, R. Zhao, and X. Hu, "Influence of Cathodic Current on Composition, Structure and Properties of $\mathrm{Al}_{2} \mathrm{O}_{3}$ Coatings on Aluminum Alloy Prepared by Micro-arc Oxidation Process," Thin Solid Films, 515 326-32 (2006).

14. T. B. Wei, F. Y. Yan, and J. Tian, "Characterization and Wear- and Corrosion-resistance of Microarc Oxidation Ceramic Coatings on Aluminum Alloy," J. Alloys Compd., 389 169-76 (2005). 